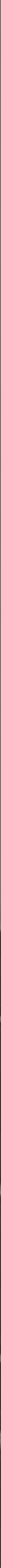




\title{
Are We Running Out of Water?
}

\author{
By Raymond L. Nace
}

GEOLOGICAL SURVEY CIRCULAR 536

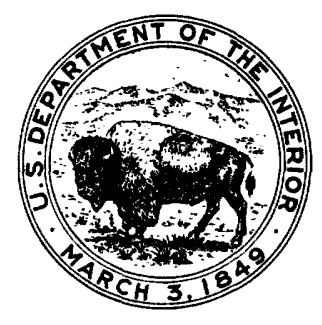




\title{
United States Department of the Interior \\ ROGERS C. B. MORTON, Secretary
}

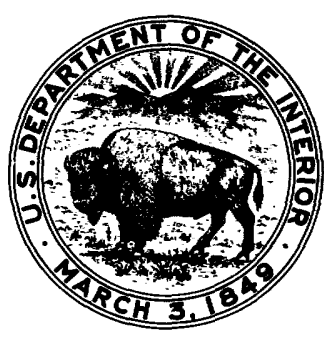

\section{Geological Survey}

V. E. McKelvey, Director

\author{
First printing 1967 \\ Second printing 1967 \\ Third printing 1975
}




\section{CONTENTS}

Page

Abstract

Introduction - . -

World water budget ................

Water resources and water availability-

Water use and consumption ........

1

1

1

4

4
Water resources and water availability-Continued Water use and management ........ 5

Conclusions ................. 6

References .

\section{ILLUSTRATIONS}

Page

Figure 1. Sketch showing relative quantities of components of world water supply

\section{TABLES}

Table 1. Estimated world water supply and budget 


\title{
Are We Running Out of Water? ${ }^{1}$
}

\author{
By Raymond L. Nace
}

\begin{abstract}
Water supplies are not running out, but time is getting short to stem waste of water and destructive exploitation of the environment before harm is done that may be irreparable. Most of the world's water is oceanic brine. Of the waters on the land, most is frozen in Antarctica and Greenland. Only a small part of continental water is available for use and management. The discharge of rivers to the sea is a close measure of the availability of liquid water, but ground-water reservoirs have important functions as inexpensive equalizers of water supply. Soil moisture is a major factor in the water economy, and its function usually is overlooked in assessments of water use and future water demand. Despite outcries of water shortage, the principal use of water in advanced countries is as a medium for waste disposal. In reality, despite regional maldistribution of water, United States supplies are adequate, given rational management. Also, contrary to common belief, water pollution is primarily a problem of economics, not of health. A paramount problem in most parts of the world is the shortage of water development and management facilities, not a shortage of water. The International Hydrological Decade is a program to awaken people everywhere to the crucial importance of water in man's future and to promote rational approach to water problems.
\end{abstract}

\section{INTRODUCTION}

"Are we running out of water?" is a question that is frequently asked or implied. But the question arises from inisunderstanding, both of water and of water problems. When an automobile "runs out" of gasoline, the fuel has been used up and none remains. No analogous event threatens water supplies. The continents are not running out of water, but men are fast running out of ways to avoid provision of adequate water works and rational management of available supplies. Societies can no longer af ford profligate waste and reckless degradation in the quality of this supposedly renewable resource. "Renewability" loses much of its significance where usefulness of the resource is destroyed almost as soon as renewal occurs.
The problem of water quality and degradation of quality goes far beyond water pollution in relation to public health. It extends to the utility of water for all purposes, to national economics, and to national cultures. And it is closely related to circulation of water in the hydrological cycle. It is worthwhile therefore to consider briefly the world water budget and water cycle.

\section{WORLD WATER BUDGET}

The total amount of water in existence is about $1.36 \times 10^{9}$ cubic kilometers $\left(=326 \times 10^{6}\right.$ cubic miles). Discouragingly enough, somewhat more than 99.4 percent of this is brine and ice in oceans, inland seas, glaciers, and polar icecaps. Table 1 summarizes some data about water, but it is difficult to visualize a billion cubic kilometers of water or a tenthousandth of one percent of a billion. Analogy may give a better concept of these relative quantities.

Let the total amount of water in existence be considered as one barrel-about 200 liters (or 55 gallons). (See fig. 1.) The ocean then may be represented as a tub containing 1951 (50 gal). Icecaps and glaciers would be a small block of ice equivalent to 4.21 of water (about 1 gal). Total water participating annually in the hydrological cycle appears as 62 milliliters (about 2 ounces) in a small water glass. Annual precipitation on the land appears as $15 \mathrm{ml}$ (half an ounce) in a liqueur glass. Fresh water discharged annually by rivers to the sea shows up as about $5 \mathrm{ml}(0.2 \mathrm{oz})$ in a small syringe. Annually recoverable ground water

\footnotetext{
'Based on a paper delivered orally at the First International Water Quality Symposium, Washington, D.C. . August 25, 1965.
} 
would be represented by about a fourth of a milliliter (one very small drop) in a hypoder mic syringe.
The total discharge of rivers is an approximate measure of potentially available and manageable liquid water in continental areas.

Table 1.-Estimated world water supply and budget

[Modified after Nace $(1960,1964)$. Values in the table are approximations based on data compiled from many sources. They should not be construed to mean that any of the values is precise. Certain minor inconsistencies between the upper and lower parts of the table do not warrant adjustment for the purposes of this paper ]

\begin{tabular}{|c|c|c|c|}
\hline \multirow{2}{*}{ Water item } & \multicolumn{2}{|c|}{ Volume (thousands) } & \multirow{2}{*}{$\begin{array}{l}\text { Percent } \\
\text { of total } \\
\text { water }\end{array}$} \\
\hline & Cubic miles & Cubic kilometers & \\
\hline \multicolumn{4}{|l|}{ Water in land areas: } \\
\hline Fresh-water lakes & 30 & 125 & 0.009 \\
\hline Saline lakes and inland seas & 25 & 104 & .008 \\
\hline Rivers (average instantaneous volume) & .3 & 1.25 & .0001 \\
\hline Soil moisture and vadose water & 16 & 67 & .005 \\
\hline $\begin{array}{l}\text { Ground water to depth of } 4,000 \mathrm{~m} \text { (about } \\
13,100 \mathrm{ft} \text { ) }\end{array}$ & 2,000 & 8,350 & .61 \\
\hline Icecaps and glaciers & 7,000 & 29,200 & 2.14 \\
\hline Total in land area (rounded) & 9,100 & 37,800 & 2.8 \\
\hline Atmosphere & 3.1 & 13 & .001 \\
\hline World ocean & 317,000 & $1,320,000$ & 97.3 \\
\hline Total, all items (rounded) & 326,000 & $1,360,000$ & 100 \\
\hline \multicolumn{4}{|l|}{ Annual evaporation: ${ }^{1}$} \\
\hline From world ocean & 85 & 350 & 0.026 \\
\hline From land areas & 17 & 70 & .005 \\
\hline Total & 102 & 420 & 0.031 \\
\hline \multicolumn{4}{|l|}{ Annual precipitation: } \\
\hline On world ocean & 78 & 320 & 0.024 \\
\hline On land areas & 24 & 100 & .007 \\
\hline Total & 102 & 420 & 0.031 \\
\hline $\begin{array}{l}\text { Annual runoff to oceans from rivers } \\
\text { and icecaps } \\
\text { Ground-water outflow to oceans }\end{array}$ & $\begin{array}{l}9 \\
.4\end{array}$ & $\begin{array}{l}38 \\
1.6\end{array}$ & $\begin{array}{c}0.003 \\
.0001\end{array}$ \\
\hline Total & 9.4 & 39.6 & 0.0031 \\
\hline
\end{tabular}

\footnotetext{
${ }^{1}$ Evaporation $\left(420,000 \mathrm{~km}^{3}\right)$ is a measure of total water participating annually in the
} hydrological cycle.

${ }^{2}$ Arbitrarily set equal to about 5 percent of surface runoff. 


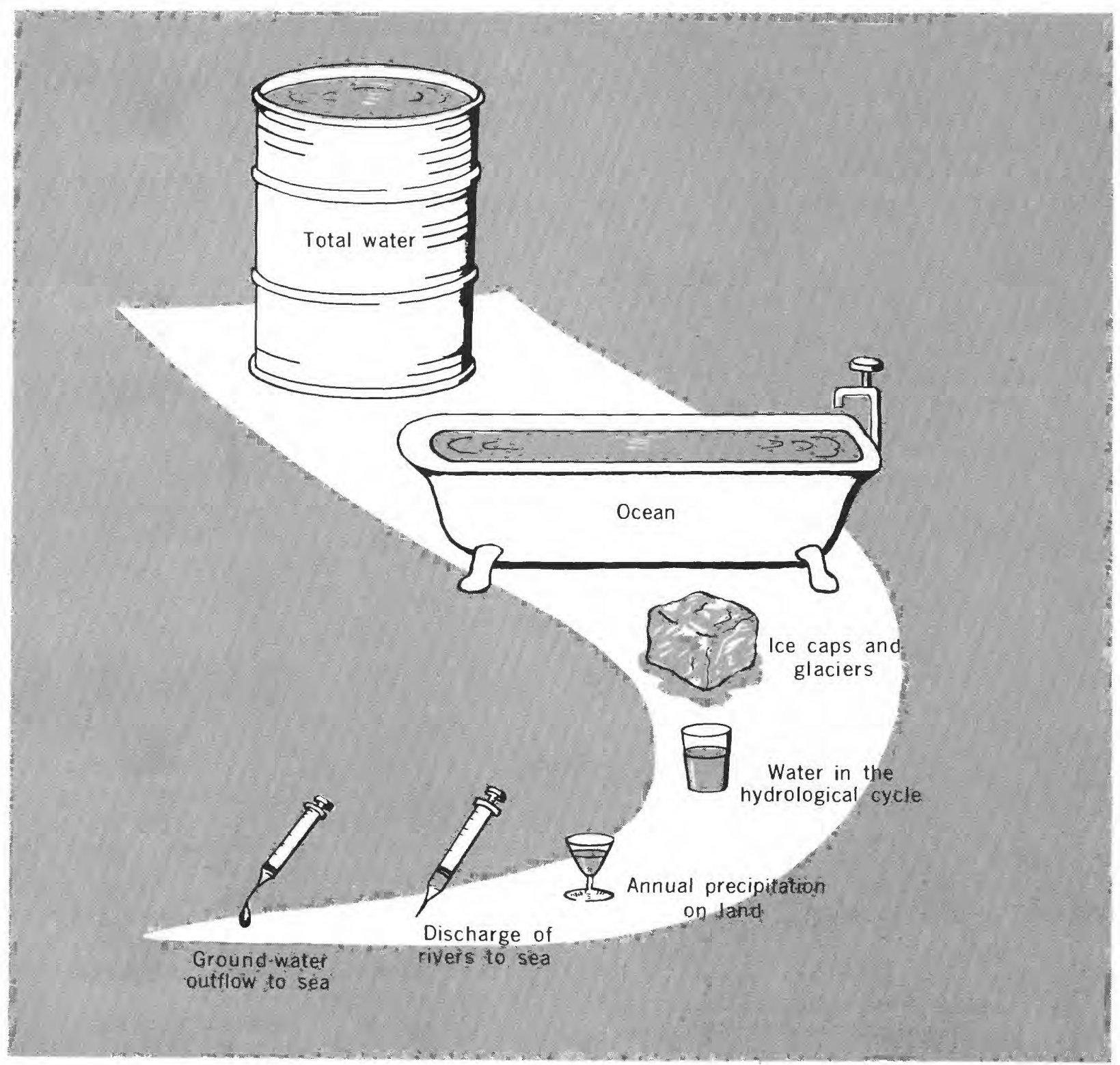

Figure 1. - Relative quantities of components of world water supply.

The hydrological cycle has operated long enough in the modern climatic regime that the large amounts of water stored in lakes and underground are in quasi-equilibrium with water in other parts of the environment. In general, a lake is a delayed river-a natural equalizer of stream flow-and upstream removal of water from a lake depletes downstream flow. Natural underground reservoirs, the repositories of ground water, also are equalizing reservoirs, and they are the principal regulators of natural streamflow. This comparison is oversimplified, but on a con- tinental scale it is substantially correct. Ground-water developments that do not deplete streamflow are either water-mining operations that cannot be continued indefinitely, or they are local salvage from evaporation and are insignificant on the continental scale. Like their surface counterparts, however, groundwater reservoirs permit use of water at different times and places and with different temperatures and chemical properties than would be possible if dependence were solely on natural flow in rivers and delay in lakes. 


\section{WATER RESOURCES AND WATER AVAILABILITY}

A resource is a stock or reserve that can be drawn on when needed. Ability to "draw on when needed" implies that the water is avail able for withdrawal at the necessary time and place and that withdrawal is practicable. Men have not learned how to control precipitationdelivery of water to the land areas-so atmos pheric water is not a resource in the present state of technology. Similarly, virtually no control of the reverse process of evaporation has been achieved. About 70 percent of precipitation on land areas evaporates more or less promptly from soil, vegetation, and water surfaces. Vast soil-moisture conservation projects in various countries have achieved control only of a minute percentage of evaporation and, for the world as a whole, evaporation control is essentially nil.

Nevertheless, soil moisture is a major factor in the water economy, and depletion of this water by whatever means in inhabited areas is a water use for human purposes. Recogni tion of that fact puts a perspective on total water use that is quite different from that to which we are accustomed. Land and water use in a region is part of the way of life of its inhabitants. If the inhabitants choose, for example, to retain vast areas in forest to provide timber, scenery, recreational facilities, and other economic and social benefits, water consumed by the forest is a consuming use for human benefit. Likewise the water consumed in huge areas of cropland, whether supplied by irrigation or by natural soil moisture, is consumed for human benefit and is part of the water requirement for the population.

Evidently, the water resources of any region consist of the percentage of total precipitation that can be "drawn on when needed." Soil moisture is available for use, at least in place, and alternative choices are available concerning specific uses, whether for timber, grassland, cropland, or other purposes. To the extent that use of soil moisture is subject to alternative choices, it is part of the resource, and soil-moisture consumption logically should be considered as a consuming use for human purposes.

\section{WATER USE AND CONSUMPTION}

Use of water for all purposes in the United States in 1960 , estimated by conventional methods, was about 1,500 gal $(5,680$ 1) per capita per day according to MacKichan and Kammerer (1961). However, only about 23 percent of the used water was consumed (turned to vapor), so per capita depletion of the resource was only 345 gal $(1,3051)$ per day.

The MacKichan-Kammerer estimates deal only with so-called withdrawal use of liquid water-that is, with water diverted from surface sources or pumped from underground. The estimates are perfectly valid within limi tations that are quite clear. But nearly all users of the data ignore the limitations and treat the estimates as though they dealt with total water supply and total use. From the planning standpoint this is plainly dangerous when the estimates are used as a basis for calculating how large a population can be supported by a given water supply without reduction in living standards.

In a realistic accounting of water resources, however, there is no more reason to exclude consumption of water by nonirrigated crops than to include water consumed by irrigated crops.

If man lived by bread alone at a bare daily subsistence level of 1 kilogram ( $2 \frac{1}{2}$ pounds) dry weight of bread, his existence would require 1,1001 (300 gal) of water a day-the amount consumed to grow the wheat (Bradley, 1962). However, for a substantial advancednation diet of vegetable matter plus animal fat and protein, the minimum per capita water consumption is 9,5001 ( 2,500 gal) per day, including water consumed by the living animal and by the plants on which it fed. This is water needed for food production only. Add water to grow cotton and wool for clothing, and the water demand goes up to $11,0001(3,000$ gal) per day -about twice the per capita withdrawal of water in the United States. This is for a subsistence-level existence only. Add the other water demands of an advanced society for industry, civilized amenities, timber production, and many other purposes, and actual daily water use per capita rises to many thousands of gallons, drawn chiefly from soil moisture. Evidently, the total environment and the total water resource of a highly developed area may limit the way of life and living stand ards of the inhabitants. The problem is not whether water supplies are running out, but whether people are outrunning the supplies. Water supplies have finite limits, but the demands of people on the supplies have no known limit. 
Actual outstripping of the supply is an event for the future, but how far in the future no one actually can say. Predictions that point to a crisis in $1980,2000,2050$, or some other year have no value because they are misleading and therefore may be dangerous. They are merely straight-line projections of historical and cur rent trends, and they seem to assume that withdrawal use of water will be as irrational in the future as it has been in the past. They are equally misleading and dangerous in that they ignore completely the nonwithdrawal use of water that maintains the environment and grows most of the food.

Turning again to conventional water-use data, average total water supply of the United States is 4.5 billion cubic meters ( 1.2 trillion gal) per day-the average daily discharge of streams. Total water use in 1960 was about 1 billion $\mathrm{cu} \mathrm{m}$ (270 billion gal) per day-about 22 percent of the total supply. But consuming use of water was only about 230 million cu $\mathrm{m}$ (61 billion gal) per day, or about 5 percent of the total supply.

If the United States consumes only 5 percent of its water supply, how can this be squared with current outcries about water shortage and a water crisis? Several answers are avail able. One answer is the polluted condition of rivers. Out of its total potentially controllable liquid assets, the United States uses 95 percent chiefly as a conveyor belt on which to send waste products out to sea. The pattern seems to be similar in much of Europe and other highly developed areas. The major use of free-running water in industrial nations is not industry, as publisned statistics seem to show, but waste disposal. So long as this co:ldition prevails, claims that water supplies are running out are groundless. The fact is that a situation has developed in which it is essential to get better use of water that is actually available. Inequities in regional water supplies pose critical development problems for specific areas, but this fact only lends emphasis to the main fact that water supplies, nationwide in the United States, are adequate under adequate management.

Waterborne disease is comparatively rare in highly developed countries because avail able technology is adequate for water treat ment. Water pollution in these countries is primarily an economic problem rather than a public health problem. Pollution is chiefly an economic problem because water supplies in most nonarid areas are sufficient in quantity for present use and for greatly expanded future use. The primary concern of societies in these areas should be, not water quantity, but rational management of available supplies and protection of their quality. This means that the water bill will get bigger. Societies can afford this bill, but they can no longer af ford to use their rivers for industrial and $\mathrm{mu}$ nicipal dumps.

\section{WATER USE AND MANAGEMENT}

Present water supplies are adequate in most parts of the world except those that are naturally and chronically arid or semiarid. But adequacy of supply is no guarantee of freedom from problems unless management is adequate.

Water management is adequate when it correctly anticipates future problems and takes timely and suitable action to cope with them. Problems are ever changing in nature and scope; their solution requires flexibility and evolution both in planning procedures and in planning policy and philosophy. I shall give only one example of hydrological information that seems to call for changed procedures in the future.

Ground-water reservoirs in North America may contain 2,000 to 3,000 times as much water as is present in river channels at any one time. They probably contain many times more water than can be stored in all the surface reservoirs that will ever be built on the continent. North American lakes contain about five times the amount of water discharged annually by rivers on the continent. In short, nature's plumbing system has built-in regulating devices that are far larger and far more effective than artificial ones. Surface-storage reservoirs, viewed in proper scale; are mere tinkerings with details of the plumbing system. These details are very important, but they are still details.

Ground-water reservoirs have several advantages: Properly managed, they do not flood valuable lowlands; evaporation rates are very low to nil; they do not silt up; they do not wear out. Water stored in many of them can be augmented by artificial recharge without costly impoundments. Many such reservoirs have tremendous unused capacity. One of the 
largest in the United States is the basalt aquifer of the Snake River Plain, which occupies an area of about $31,000 \mathrm{sq} \mathrm{km}(12,000 \mathrm{sq} \mathrm{mi})$. A 10 -meter thickness of this aquifer, assuming only 5-percent effective porosity, could hold $1.6 \times 10^{9} \mathrm{cu} \mathrm{m}\left(56 \times 10^{9} \mathrm{cu} \mathrm{ft}\right)$ of water. This is somewhat more than a third of the annual dis charge of the Snake River at King Hill (which is $5.3 \times 10^{9} \mathrm{cu} \mathrm{m}$ per $\mathrm{yr}=190 \times 10^{9} \mathrm{cu} \mathrm{ft}$ ) at the western edge of the aquifer. Considering that the basalt has 500 to 1,000 feet of unsaturated thickness above the water table in large areas, its potential for storage far exceeds the amount of water available for additional storage. The Snake River basalt and many other aquifers in the world-in fact, all nature's underground regulating devices-merit careful study of their storage capabilities. Full knowledge of these capabilities could well lead to more ef fective water-resource management than all potentials for manipulating streamflow by surface reservoirs. A few studies toward that end already are underway. New perspectives in water-management possibilities require much more concerted, unremitting exploration of possibilities.

\section{CONCLUSIONS}

Societies throughout the world face very real problems which involve water, but they are not primarily problems of water quantity. Rather, they are problems of people, of their attitudes toward water, and of what they do with and to it. For the United States as a whole, there is no shortage of water-only a shortage of wa terworks and developments. Studies in several European countries show similar situations there.

Consideration of water problems solely as functions of streamflow and withdrawal use is an evasion of the real situation. Water need per individual in industrial societies is nearly ten times greater than has been supposed, and the population that can be supported with acceptable living standards undoubtedly is much smaller than some writers have calculated on the basis of unrealistic assumptions.

Paramount among water problems is that of maintaining good water quality. Many towns and industries are unable or unwilling to pay the cost of cleaning up their own waste water. The attitude is, "My downstream is your upstream, and my waste is your problem." But in industrialized areas technology and financial means are available to maintain quality.
Only rational decision and payment of reasonable cost are required to cope with situations.

The situation is far different in the less developed areas of the world, comprising 75 countries in Africa, Asia and Latin America. Surveys in 60 of those countries (World Health Organization, 1964) show that an urban population of $218,140,000$ (90 percent of the total population) depends on water supplies that are inadequate or unsafe. At least 70 percent of the urban population relies on unpiped water from wells, rivers, and other sources that are vulnerable to contamination. There, no less than in the United States, the dominant shortage is of water development and waterworks, not of water.

In view of the universal prevalence of water problems, the world can ill afford to remain passive so long as it lacks means for fully ef fective management of its aggregate water supply. Management must assure both adequate quantity and good quality. One critical existing deficiency is in hydrological knowledge on a global scale. Hydrologists and allied scientists have taken an important specific forward step, with endorsement by many national governments, by proposing that UNESCO (United Nations Scientific, Educational and Cultural Organization) sponsor an IHD (International Hydrological Decade) aided by other international agencies and scientific associations. The IHD is a program on a worldwide scale to (1) advance knowledge of hydrology, especially on continental and global scales, (2) to make the benefits of water science more widely available and us eful, alike to developed and developing countries, (3) to promote education and training in hydrology, and thus (4) to improve the ability of all countries to cope with their water problems.

Already 94 countries have joined the program. The United Nations, World Meteorological Organization, Food and Agriculture Organization, World Health Organization, and International Atomic Energy Organization-all have expressed lively interest in the IHD and, in cooperation with UNESCO, are participating. The program started officially in January 1965. Participants have reason to hope that the IHD will be one of the most productive large international programs yet launched.

It has been said that the basic problem during the next 100 years will be whether man can learn to live with man. The water situation 
will have much to do with the ability of men to live peaceably together. No human crisis centering around water exists today, but one is visible on the horizon. An ultimate purpose of the IHD is to help forestall that crisis.

\section{REFERENCES}

Bradley, C. C., 1962, Human water needs and water use in America: Science, v. 138, p. 489-491.
MacKichan, K. A., and Kammerer, J. C., 1961, Estimated use of water in the United States in 1960: U.S. Geol. Survey Circ. 456, 44 p. Nace, R. L., 1960, Water management, agriculture, and ground-water supplies: U.S. Geol. Survey Circ. 415, 12 p.

1964, Water of the world: Nat. History Mag., v. 73, p. 10-19.

World Health Organization, 1964, Community water supply programme: WHO Official Recs., no. 135, annex 10, 21 p. 
